Harbour entirely surrounds a mass of sediment hitherto regarded as a partition wall, projecting between two contiguous necks. This agglomerate is therefore now considered to belong to one neck in which a large mass of sedimentary material has been enclosed. A small vent pierces the Earlsferry Coals. The material of this neck is peculiar, consisting mainly of basalt and "White Trap."

Several crystals of zircon in the agglomerate at Elie Ness verify the discovery of zircon at this locality by Traill, mentioned in Heddle's Mineralogy of Scolland.

A boulder of glauconitic sandstone containing Lower Greensand fossils was found in the Arctic Shell-bearing Marine Clay in Woodhaven.

\title{
OBITUARY.
}

\section{Charles Doolittle Walcott, LL.D., Sc.D., Ph.D.}

BORN 31st MARCH, 1850.

Died 8Th February, 1927.

The death of Dr. Walcott has deprived us of one of the world's leading geologists who, having made his first geological excursion in his thirteenth year, had pursued the study of the science forsixtyfour years. Although occupied during a large part of his life with important administrative work, this did not prevent him from carrying out researches of the highest value.

In 1876 Walcott was appointed assistant to Professor James Hall, the State Geologist of New York, and three years later. became Assistant Geologist on the United States Geological Survey. In the ensuing years he did much field work, particularly in the Western States. In 1888 he was appointed palaeontologist to the Survey, with charge of the invertebrate fossils, and in 1894 Director of the Survey. This post he held until 1907, when he obtained the "blue ribbon " of science in the United States, being made Secretary of the Smithsonian Institution.

During his latter years Walcott devoted special attention to the organisms of the Algonkian and Lower Palaeozoic rocks, more particularly to the sequence of the Cambrian faunas of the States and Canada. In his last years he visited, season after season, the mountain region of British Columbia, establishing a detailed sequence of the various faunas and describing the characters of the principal organisms. His work on the Trilobites and their allies and on the Brachiopods is particularly noteworthy. Walcott's masterly monograph on the Cambrian Brachiopoda appeared in 1912 ; and year by year he issued memoirs on the Trilobites and other fossils. Many of these were preliminary to further studies, but he has left a mass of material for use by those who have been trained by him. 
We may specially refer to his monograph on The Fauna of the Lower Cambrian or Olenellus Zone, 1890, and to the large series of memoirs on Cambrian Geology and Palaeontology, writings of high importance and embodying the results of a prodigious a mount of work.

It was fortunate that Walcott was able to pursue his detailed studies on the Mt. Stephen formation of British Columbia, one horizon in which may well be described as the "Solenhofen slate" of the Lower Palaeozoic period, so beautifully are its organisms preserved, and the work thereon will be of incalculable benefit to geologists and biologists alike.

Walcott was a man of commanding presence and magnificent physique. His friendship was a possession of which to be proud. He was a genuine lover of nature, evidence of which is furnished both by his published works and his private correspondence. In the study of the Cambrian System he forms one of a great trioSedgwick, Barrande, Walcott, and his name will ever be enrolled in the list of the world's great geologists.

J. E. M.

\section{Leslie D. Currie, B.Sc.}

BORN 19TH APRIL, 1904.

DIED 9TH NOVEMBER, 1925.

We regret to announce the death of Leslie D. Currie, who was drowned while bathing in Burma. Mr. Currie, after a brilliant career at Glasgow University, had just joined the staff of the Burma Oil Company as palaeontologist. After completing his degree he spent twelve months on research work on some undescribed Crustacea from the Silurian rocks of Lesmahago. A paper on a new Xiphosuran is published in this Magazine, but his main work on another series was still incomplete. By his death palaeontology has lost a very promising worker.

J. W. G. 